PERRUD, AC; BAVARESCO, LG; ZEIST, AR; LEAL, MHS; SILVA JÚNIOR, AD; RESENDE, JTV; SILVA, ML; TOROCO, BR. 2021. Relationship between bud number in seed branches and yield aspects of sweet potato. Horticultura Brasileira 39: 451-457. DOI: http://dx.doi.org/10.1590/s0102-0536-20210415

\title{
Relationship between bud number in seed branches and yield aspects of sweet potato
}

\author{
Amanda C Perrud ${ }^{1} \mathbb{D}$; Lorrayne G Bavaresco ${ }^{1} \mathbb{D}$; André R Zeist ${ }^{2} \mathbb{D}$; Murilo HS Leal ${ }^{1} \mathbb{D}$; André D Silva \\ Júnior ${ }^{1} \mathbb{D}$; Juliano TV de Resende ${ }^{3} \mathbb{D}$; Marcio L da Silva ${ }^{1} \mathbb{D}$; Bruno R Toroco ${ }^{1} \mathbb{D}$
}

${ }^{1}$ Universidade do Oeste Paulista (UNOESTE), Presidente Prudente-SP, Brasil; amanda_perrud@hotmail.com; lgbavaresco@hotmail.com; murilolea18@gmail.com; andrejunior018@gmail.com; marcinho11do11@hotmail.com; bruno-taroco@hotmail.com; ${ }^{2}$ Universidade Federal de Santa Catarina (UFSC), Florianópolis-SC, Brasil; andre.zeist@ufsc.br; ${ }^{3}$ Universidade Estadual de Londrina (UEL), Londrina-PR, Brasil; jvresende@uel.br

\begin{abstract}
Planting sweet potato branches with the appropriate bud number and disposition, below and above ground, can favor vegetative growth and yield that better fit the marketable standards. This study aimed to explore the influence of the number of buds and their distribution ratio, above and below ground level, on the agronomic and marketable components of sweet potato tuberous roots. The experiment was carried out in a randomized complete block design with three replications. The treatments were arranged in a factorial scheme $(3 \times 5)$, with 2,4 , and 8 above-ground buds combined with 2, 4, 6, 8, and 10 below-ground buds. Branches from the UZBD 06 accession (Canadense standard) were used. Vegetative, productive, and marketable traits of roots were evaluated. The use of branches with a greater number of buds above and below ground increased shoot dry biomass. Planting seed branches with 8 buds above and 8 buds below ground provided a greater number and production of marketable roots. The use of 10 buried buds increased root number and yield in the 150-450 g marketable classes, which the consumer market values the most.
\end{abstract}

Keywords: Ipomoea batatas, marketable classes, tuberous roots, propagation structure.

\section{RESUMO}

Relação entre número de gemas nas hastes e aspectos de produção da batata-doce

O plantio de hastes de batata-doce com o número e disposição adequados de gemas, abaixo e acima do solo, pode favorecer o crescimento vegetativo e a produção que melhor atendem aos padrões comercializáveis. Este estudo teve como objetivo explorar a influência do número de gemas e sua proporção de distribuição, acima e abaixo do nível do solo, sobre os componentes agronômicos e comercializáveis de raízes tuberosas da batata-doce. O experimento foi conduzido em delineamento de blocos ao acaso com três repetições. Os tratamentos foram arranjados em esquema fatorial (3 x 5), com 2, 4 e 8 gemas acima do solo combinadas com 2, 4, 6, 8 e 10 gemas abaixo do solo. Foram utilizadas ramas do acesso UZBD 06 (padrão canadense). Foram avaliadas as características vegetativas, produtivas e comercializáveis das raízes. O uso de ramas com maior número de gemas acima e abaixo do solo aumentou a biomassa seca da parte aérea. O plantio de ramas com 8 gemas acima e 8 gemas abaixo do solo proporcionou maior número e produção de raízes comercializáveis. O uso de 10 gemas enterradas aumentou o número de raízes e o rendimento nas classes comercializáveis de 150-450 g, mais valorizadas pelo consumidor.

Palavras-chave: Ipomoea batatas, classes comerciais, raízes tuberosas, estrutura de propagação.

Received on December 21, 2020; accepted on October 14, 2021

$\mathrm{S}_{\mathrm{a}}^{\mathrm{n}}$ weet potato (Ipomoea batatas) is an economically important crop, the fourth most consumed vegetable in Brazil. It serves as human and animal food, as well as raw material for the industry and biofuel production (Vargas et al., 2017, 2018). Being a rustic plant, originated in Central America, sweet potato is widely adapted to various soil types, in addition to being tolerant to drought and high temperatures, which allow its cultivation in different regions of the world (Santos Junior et al., 2020;
Teshome et al., 2020).

Sweet potato yields approximately $14.00 \mathrm{t} \mathrm{ha}^{-1}$ in Brazil, above the world average estimated at 11.40 t ha-1 (FAO, 2020). Nevertheless, Brazilian productivity is low compared to countries such as Portugal (25.42 t ha-1), Egypt (33.57 t ha $\left.{ }^{-1}\right)$, Australia (36.42 $\mathrm{t} \mathrm{ha}^{-1}$ ), and Senegal (40.41 $\left.\mathrm{t} \mathrm{ha}^{-1}\right)$. One way to improve sweet potato yield and quality is to adopt appropriate management techniques in the production fields (Yan et al., 2017).
Among these techniques, the use of proper propagation structures may be the first and most important step in this process. Nonetheless, farmers neglect this step, giving little importance to the choice and preparation of seed branches (planting vines) for setting up commercial areas (Thompson et al., 2017).

In tropical and subtropical regions, sweet potato is propagated vegetatively, usually through seed branches or unrooted stem cuttings (Loebenstein, 
2015). Farmers usually plant 30-40 $\mathrm{cm}$ long seed branches, often taken from plants grown in commercial production fields. The branches are obtained from the shoot tip of the parent plant and are then distributed in planting windrows, burying half under the ground (Santos \& Ferreira, 2018; Nasser et al., 2020). Bud number in seed branches can vary depending on plant genotype, age, nutritional status, environmental conditions, and water availability (Bunphan \& Anderson, 2019). However, when farmers plant sweet potato seed branches based on vine length, they disregard that bud number and disposition in the ground can affect plant survival, arrangement in the field, and growth and productive performance (Beyene et al., 2015).

Using vines with an adequate bud number favors early vegetative growth and anticipates tuberous root formation compared with stem cuttings with fewer buds. Thus, vine size must be specific for each cultivar and growing environment. Too long branches can generate waste of propagating material, while shorter ones can delay plant establishment and result in poor productive performance (Essilfie et al., 2016). Regarding the buried vine portion, the higher or lower number of buds inside the soil can influence tuberous root yield and quality (Rós, 2017; Azevedo et al., 2000). The number of above-ground buds can also influence vegetative development and production. However, no studies have been reported on the influence of aboveground bud number in planting vines.

To better serve the export market, attention should be paid to tuberous roots weight, in which the range of 300$450 \mathrm{~g}$ is the most valued by the market. Thus, an essential aspect in sweet potato production is yield linked to marketable classes. Although there is evidence that vine size at planting contributes to the average mass and yield of sweet potato (Beyene et al., 2015; Thompson et al., 2017), conflicting results are shown in the literature (Rós, 2017).

Studies aiming to define the ideal size of planting vines generally consider the yield components, neglecting important commercialization aspects, such as those related to sweet potato marketable classes. The scarcity of technical-scientific information to achieve better yield and quality of marketable roots entails the need for studies to strengthen the sweet potato production chain (Mukhopadhyay et al., 2011; Echodu et al., 2019). Considering the above information, this work aimed to evaluate the influence of the number of buds in seed branches and their distribution ratio, above and below ground level, on the agronomic and marketable components of sweet potato tuberous roots.

\section{MATERIAL AND METHODS}

The experiment was conducted in the spring-summer cycle of 2019/2020 in the Center for Studies in Vegetables and Fruits of Western São Paulo University UNOESTE $\left(22^{\circ} 07^{\prime}\right.$ 'S, $51^{\circ} 27^{\prime \prime} \mathrm{W}, 413$ $\mathrm{m}$ altitude). According to Köppen's classification, the climate of this area belongs to the Aw type, with $25^{\circ} \mathrm{C}$ average annual temperature and 1400 $1500 \mathrm{~mm}$ average annual precipitation, hot and humid summers and mild and dry winters. The soil is classified as Dystrophic Red Argillosol of medium texture (Embrapa, 2018).

Soil was sampled in the $0-0.20 \mathrm{~m}$ depth layer for chemical analysis, with the following results: $\mathrm{pH} 5.1 \mathrm{CaCl}_{2}, 9.7$ $\mathrm{mg} \mathrm{dm}$ of $\mathrm{P}, 19 \mathrm{mmol}_{\mathrm{c}} \mathrm{dm}^{-3}$ of $\mathrm{H}+\mathrm{Al}$, $2.0 \mathrm{mmol}_{\mathrm{c}} \mathrm{dm}^{-3}$ of $\mathrm{K}, 7.0 \mathrm{mmol}_{\mathrm{c}} \mathrm{dm}^{-3}$ of $\mathrm{Ca}, 3.3 \mathrm{mmol}_{\mathrm{c}} \mathrm{dm}^{-3}$ of $\mathrm{Mg}$, and 12.3 $\mathrm{mmol}_{\mathrm{c}} \mathrm{dm}^{-3}$ of base saturation.

The experiment was conducted in a randomized block design with a $3 \times 5$ factorial scheme and three replications. The treatments consisted of planting vines (seed branches) with three numbers of above-ground buds $(2,4,8)$ and five numbers of belowground buds $(2,4,6,8,10)$, totaling fifteen treatments. The combination of bud numbers above and below ground ranged from 4 to 18 buds per vine. The useful area of each plot was $4 \mathrm{~m}^{2}$, containing 10 seed branches, with 0.33 $\mathrm{m}$ between plants and $1.0 \mathrm{~m}$ between windrows (0.4-0.5 m high). The plant material used consisted of branches of the Canadense standard accession UZBD 06 belonging to the Vegetable
Germplasm Bank of the University of Western São Paulo from the shoot tip of plants kept in maintenance nurseries, free of pathogens and pest arthropods.

In soil preparation, two heavy plows and three light harrowings were carried out. Crop treatments, liming, and base and cover fertilization were performed according to the soil chemical analysis and following recommendations for the crop (Echer et al., 2015). Fertilization was done in the planting furrow, applying $20 \mathrm{~kg} \mathrm{ha}^{-1}$ of $\mathrm{N}, 80 \mathrm{~kg} \mathrm{ha}^{-1} \mathrm{P}_{2} \mathrm{O}_{5}$, and $60 \mathrm{~kg} \mathrm{ha}^{-1} \mathrm{~K}_{2} \mathrm{O}$. Topdressing was divided into two applications of $30 \mathrm{~kg}$ ha $^{-1}$ of $\mathrm{N}$ and $\mathrm{K}_{2} \mathrm{O}$ at 30 and 60 days after planting. The experiment was irrigated using a micro-sprinkler according to the crop water requirements. Weeds were controlled manually and, for the control of arthropod pests and diseases, flutriafol and casugamycin were applied preventively, according to the manufacturer's recommendations.

After 140 days of planting, shoots and tuberous roots were harvested. To obtain shoot dry biomass, the leaves and branches were oven-dried at $65^{\circ} \mathrm{C}$ until obtaining constant weight. The material was then weighed on a $0.0001 \mathrm{~g}$ precision scale. Marketable root number and yield were obtained by counting and weighing roots on a scale with a precision of $0.01 \mathrm{~g}$. Marketable roots were defined as tuberous roots with more than $80 \mathrm{~g}$, uniform shape, without mechanical damage or damage from pests or cracks (Embrapa, 1995). The average mass of marketable roots was determined by the relationship between production and number of marketable roots. The marketable tuberous roots were individually weighed and classified in the classes: $80-150 \mathrm{~g}, 151-300 \mathrm{~g}, 301-$ $450 \mathrm{~g}, 451-600 \mathrm{~g}, 601-850 \mathrm{~g}$, and above $850 \mathrm{~g}$.

The obtained data were tested for normality and homogeneity of residual variances by the Lilliefors and Bartlett tests, respectively. Once these assumptions were met, the data were subjected to the $\mathrm{F}$ test through analysis of variance, observing the factorial scheme. Data referring to above-ground bud number per vine and commercial grades were compared by mean comparison tests $(\mathrm{P} \leq 0.05)$. 
The data referring to below-ground bud number per vine were subjected to regression analysis, estimating the maximum or minimum points of the function. Statistical analyses were performed using the AgroEstat program (Barbosa \& Maldonado Junior, 2010).

\section{RESULTS AND DISCUSSION}

An interaction was observed between number of buds above and below ground for all studied characters. Planting vines with more buds above and below ground increased sweet potato shoot biomass by $112.16 \%$ and $87.43 \%$, respectively, compared to the lower number of buds tested (Figure 1). The greater vegetative growth of plants can be attributed to the rapid initial formation of new leaves and shoots from pre-existing meristematic buds in the branches, allowing greater photosynthetic capacity and efficiency in energy assimilation. In addition, the higher number of buried buds can provide higher emission of adventitious roots, increasing the potential for water and nutrient absorption and favoring the vegetative development of plants (Belehu et al., 2004).

Due to its highly ramified root system, sweet potato has a high capacity for soil exploration, making it more efficient in nutrient absorption and exportation (Guimarães et al., 2018). Thereby, the combination of 8 buds above and 10 buds below ground has the potential to produce more biomass. Besides providing important attributes to the plant physiology, shoot biomass is an excellent food to be included in animals' diet due to the high percentage of crude protein and digestibility (Monteiro, 2007; Massaroto, 2008).

More marketable roots were produced using vines containing 8 above-ground and 8 below-ground buds, reaching an estimated maximum of 85,965 roots ha $^{-1}$ (Figure 2A). On the other hand, the smallest number of buried buds caused an average reduction of $39.62 \%$ in tuberous roots number, resulting in 47,407 roots ha ${ }^{-1}$. Through the regression equation, it was possible to infer that the highest yield of marketable sweet potato roots was obtained with the combination of 8 and 7 buds, above and below ground, respectively, with a production of 35.77 $t_{\text {ha }}{ }^{-1}$ (Figure 2B).

It is assumed that vines with fewer buds require more time to establish in the field, resulting in lower yields (Muli \& Mwakina, 2016). Beyene et al. (2015) evaluated the use of 5, 7, and 9 buds per planting vine and found an increase in shoot biomass production and a greater number of sweet potato tuberous roots as the bud number per vine increased. Likewise, Essilfie et al. (2016), in a study using 4,5 , and 6 buds per vine, reported that greater number of buds per vine led to higher yield of marketable sweet potato roots.

Thompson et al. (2017) obtained better plant establishment, number of tuberous roots, and sweet potato yield, planting $16-27 \mathrm{~cm}$ long vines containing an average of 7 to 9.8 buds per stem cutting. According to these authors, the increase in sweet potato yield due to the use of long planting vines is associated with greater number of buds buried in the soil, representing potential sources of adventitious root development and storage root formation. On the other hand, Rós (2017) did not observe the influence of the number of buried buds on the number and yield of marketable sweet potato roots when evaluating 2,4 , 6 , and 8 buds below ground.

Tuberous roots develop from preformed and undamaged root primordia of nodes contained in sweet potato vines (Belehu et al., 2004). According to Ma et al. (2015), the nodal position significantly affects sweet potato root number and development, with a higher root initiation capacity from the $9^{\text {th }}$ to $13^{\text {th }}$ node of seed branches than younger nodes located between the $3^{\text {rd }}$ and $8^{\text {th }}$ positions. Our results corroborate this statement; the combination of the highest number of buds above and below ground allowed more basal buds to be buried, which may have accelerated root initiation and improved the productive performance of the plants.

The relationship between marketable roots number and production showed a decline in the average mass of tuberous roots with the increase in buried buds. The combination of 4 buds above and 2 buds below ground provided greater root mass $(560.0 \mathrm{~g})$. On the other hand, the use of 4 to 8 buried buds allowed similar performances, with roots having an average mass of 444.0 g. The production of sweet potato with lower average mass was observed using 10 buried buds, with $356.0 \mathrm{~g}$ root $^{-1}$ (Figure $2 C$ ). Similar results were observed by Fernandes et al. (2021), in a study carried out in the state of São

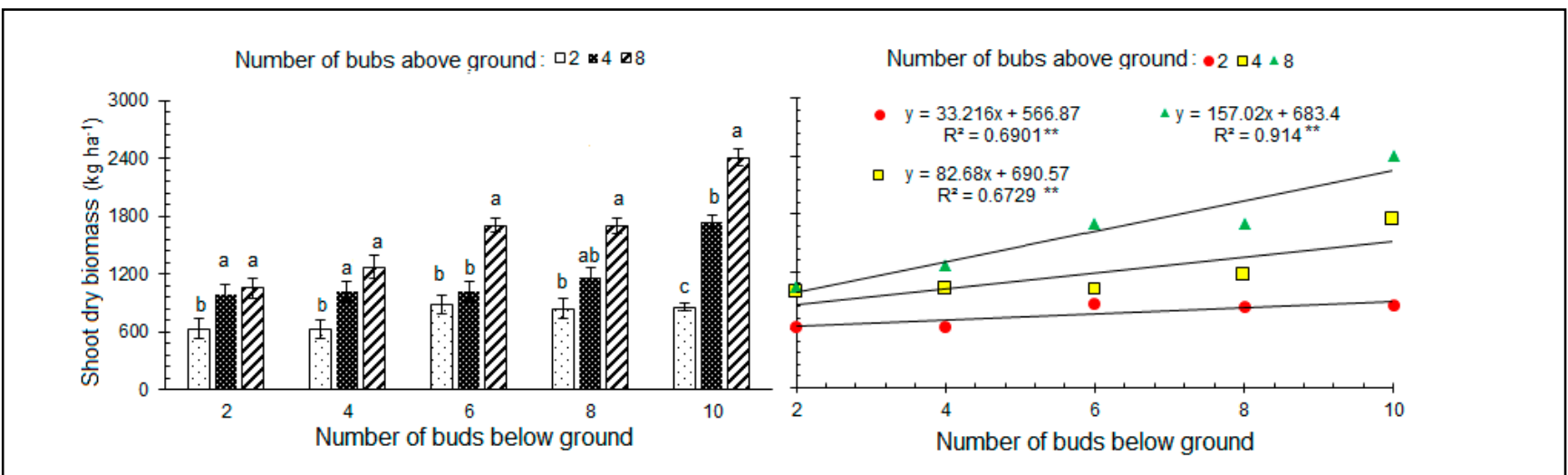

Figure 1. Sweet potato shoot dry biomass according to the number of above- and below-ground buds in seed branches. Means followed by the same letter over the columns do not differ by Tukey's test $(P \leq 0.05)$. Presidente Prudente, UNOESTE, 2020. 


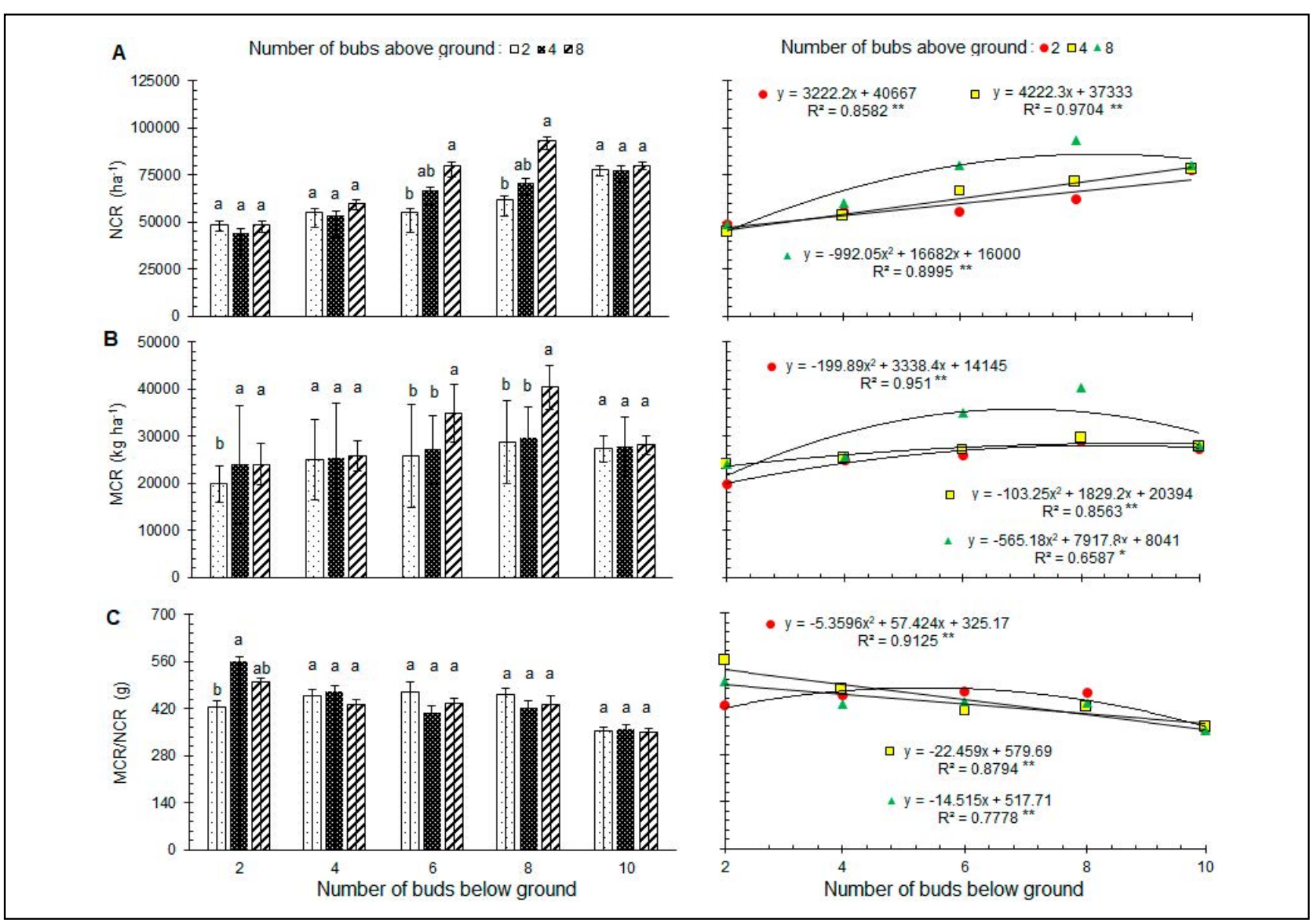

Figure 2. (A) Number of marketable roots (NCR), (B) total mass of marketable roots (yield; MCR), and (C) average mass of marketable roots (MCR/NCR) of sweet potato according to the number of above- and below-ground buds in seed branches. Means followed by the same letter over the columns do not differ by Tukey's test $(P \leq 0.05)$. Presidente Prudente, UNOESTE, 2020.

Paulo, planting cv. Canadense with 40 $\mathrm{cm}$ long seed branches and burying 3-4 internodes, resulting in sweet potato root yield greater than $32 \mathrm{tha}^{-1}$, with an average weight of $392.8 \mathrm{~g}$.

Generally, the average root mass is related to growth parameters, such as fresh and dry shoot biomass (Guimarães et al., 2002). Guimarães et al. (2018) observed that sweet potato genotypes with higher average root mass have higher fresh and dry shoot mass. The same result was observed by Oliveira et al. (2015), which showed that some genotypes had an increasing relationship between shoot dry mass production and root yield. In the present study, it was also verified that greater plant shoot was related to higher number of tuberous roots; however, the average mass was reduced.

Sweet potato yield is related to the plant photosynthetic potential (source) and capacity to accumulate photoassimilates in the roots (drain). As a perennial plant with continuous tuberization, sweet potato needs a balance between input and demand for photoassimilates (Erpen et al., 2013). The translocation of photoassimilates presents high competition between root and shoot. Therefore, greater vegetative growth may cause a small individual cumulated balance in storage roots (Pérez-Pazos et al., 2021). Furthermore, the greater number of tuberous roots increases the number of dependent drains on the shoot, reducing the fraction of assimilates for each root. Therefore, the increase of roots with smaller caliber can cause a reduction in yield. However, consumer preference for smaller roots and their higher commercial market value can compensate for this reduction.

Maximum values of marketable roots number were observed in the classifications of 301-450 g, 151-300 g, and $151-450 \mathrm{~g}$, when 2,4 , and 8 buds above ground were planted, respectively (Figure 3). Compared to the other treatments, planting vines with 8 aboveground buds provided a greater number and production of marketable roots in classes from 151 to $850 \mathrm{~g}$ (Figure 3).

Regarding the number of buds below ground, 10 buried buds led to greater number and production of marketable roots in the 80-450 $\mathrm{g}$ classes and lower yield in the $>850 \mathrm{~g}$ class. For weight classes between 451 and $850 \mathrm{~g}$, the use of 8 below-ground buds was highlighted, with 28,149 marketable roots ha ${ }^{-1}$ and $16.56 \mathrm{t} \mathrm{ha}^{-1}$. The reduction of belowground buds increased the number of marketable roots weighing more than $850 \mathrm{~g}$; consequently, the production of these roots also increased, mainly with the use of 2 buried buds, reaching 7.14 t ha ${ }^{-1}$ (Figure 4). 

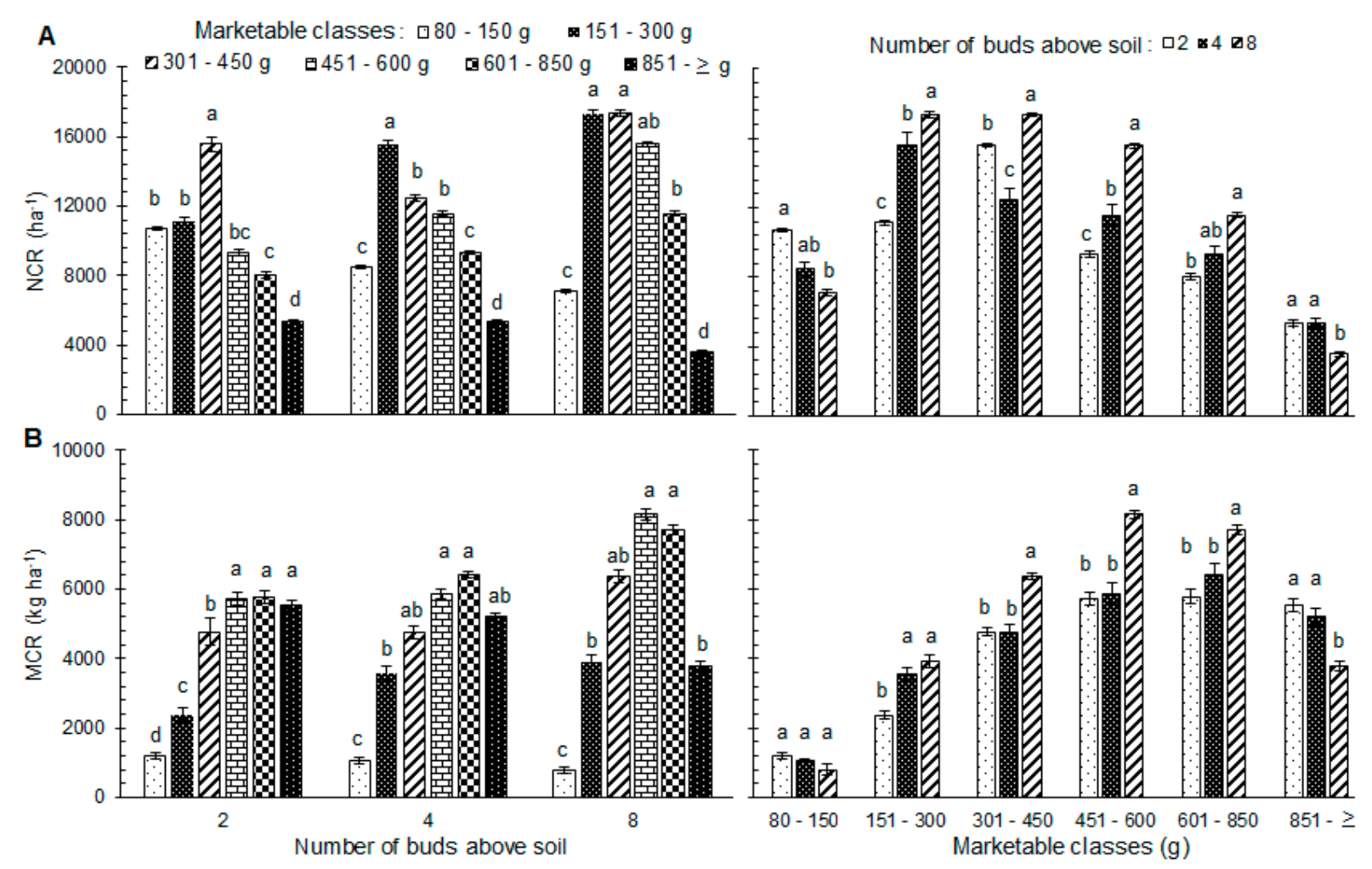

Figure 3. (A) Number of marketable roots (NCR) and (B) total mass of marketable roots (yield; MCR) of sweet potato that fitted marketable classes according to the number of above-ground buds in seed branches. Means followed by the same letter over the columns do not differ by Tukey's test $(P \leq 0.05)$. Presidente Prudente, UNOESTE, 2020.

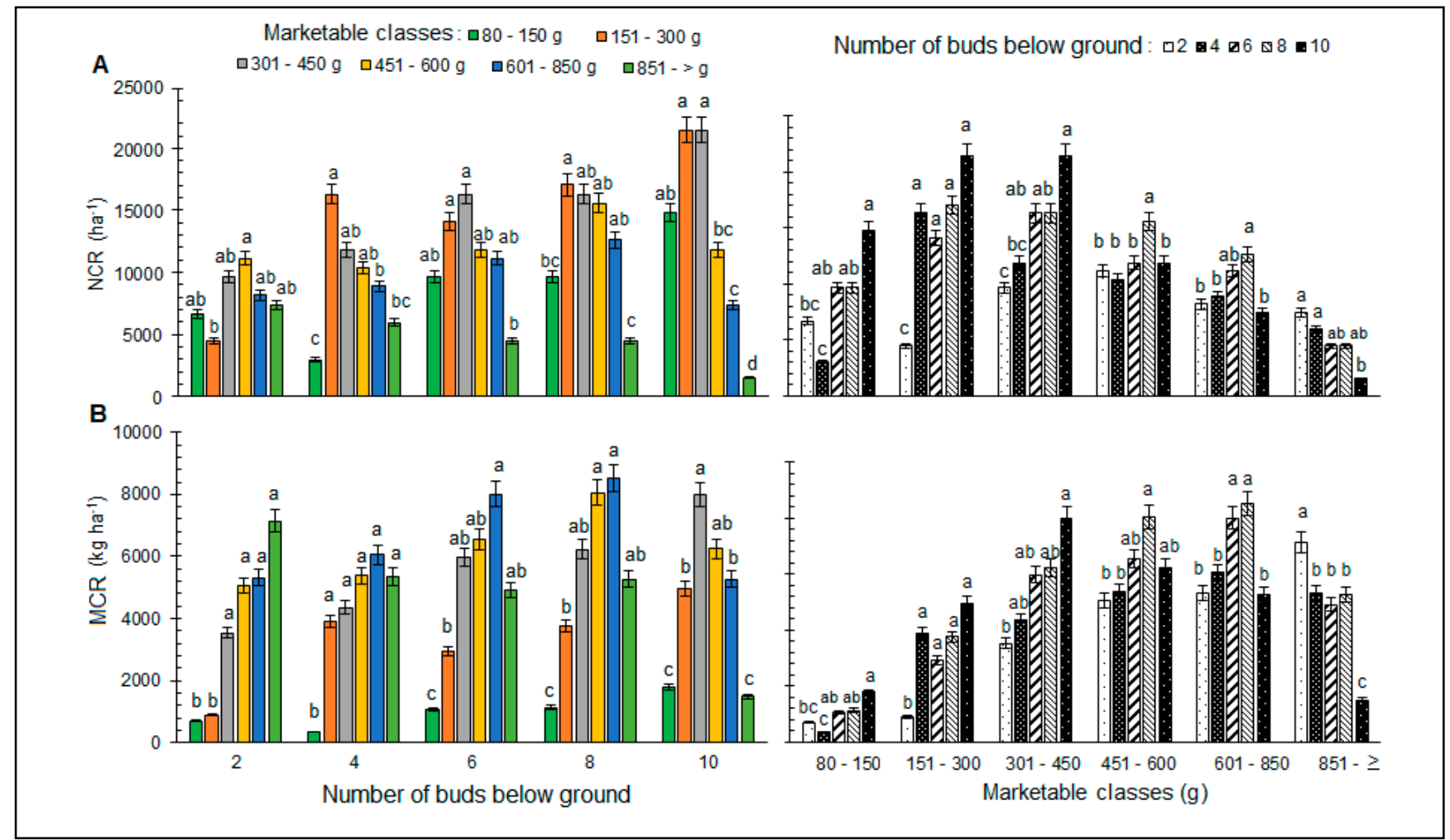

Figure 4. (A) Number of marketable roots (NCR) and (B) total mass of marketable roots (yield; MCR) of sweet potato that fitted marketable classes according to the number of below-ground buds in seed branches. Means followed by the same letter over the columns do not differ by Tukey's test $(P \leq 0.05)$. Presidente Prudente, UNOESTE, 2020. 
From this work, it was observed that the increase in bud number provides greater yield of marketable roots weighing between 150 and 400 $\mathrm{g}$, which are the most valued in the commercialization of fresh sweet potato. On the contrary, the use of fewer nodes increases the production of tuberous roots with greater individual weight, which can be used in industrial processing (Silva et al., 2008; Massaroto et al., 2014; Nogueira et al., 2016). Unfortunately, sweet potato lacks official classification standards, making it challenging to value tuberous roots with greater uniformity of weight and size. Therefore, the commercialization of sweet potato is often carried out based on the average weight of roots in the package, establishing a difference in relation to the average, which can vary by $25 \%$ (CEAGESP, 2014). However, $300-450 \mathrm{~g}$ sweet potatoes are the most valued by the consumers market and the most desired by more demanding export markets, such as those in the United Kingdom.

Several aspects must be considered when choosing the number of buds of sweet potato seed branches, such as the form of commercialization, fresh or processed. Planting vines with a greater number of buds above and below ground favors the production of sweet potato shoot biomass. Although Canadense standard genotypes are mainly used to commercialize tuberous roots, producers can benefit from using shoot biomass in animal feed. Furthermore, based on the results of this work, for growers who aim to increase the number and yield of total marketable roots, it is recommended to plant vines with 8 buds above and 8 buds below ground. On the other hand, for more demanding markets for fresh commercialization and destined for export, vines with 8 buds above and 10 buds below the ground are recommended, concentrating tuberous roots number and yield in the marketable classes between 150 and $450 \mathrm{~g}$.

\section{REFERENCES}

AZEVEDO, SM; FREITAS, JA; MALUF, WR; SILVEIRA, MA. 2000. Desempenho de clones e métodos de plantio de batata-doce. Acta
Scientiarum. Agronomy 22: 901-905.

BARBOSA, JC; MALDONADO JUNIOR, W. 2010. AGROESTAT: Sistema para análises estatísticas de ensaios agronômicos. Versão 1.0. Jaboticabal: Unesp.

BELEHU, T; HAMMES, PS; ROBBERTSE, PJ. 2004. The origin and structure of adventitious roots in sweet potato (Ipomoea batatas). Australian Journal of Botany 52: 551.

BEYENE, K; NEBIYU, A; GETACHEW, M. 2015. Effect of number of nodes and storage duration of vine cuttings on growth, yield and yield components of sweet potato (Ipomoea batatas L.) at Jimma, southwest Ethiopia. Journal of Biology, Agriculture and Healthcare 5: 22.

BUNPHAN, D; ANDERSON, WF. 2019. Effect of planting pattern and season on some agronomic performances and yield of sweet potato cv. Japanese Orange. Australian Journal of Crop Science 13: 1067-1073.

CEAGESP. 2014. Companhia de Entrepostos e Armazéns Gerais de São Paulo. Available at < http://www.ceagesp.gov.br/>. Accessed October 29, 2020.

ECHER, FR; CRESTE, JE; TORRE, EJR. 2015. Nutrição e adubação da batata-doce. Presidente Prudente, BR: UNOESTE. 94p

ECHODU, R; EDEMA, H; WOKORACH, G; ZAWEDDE, C; OTIM, G; LUAMBANO, N; ATEKA, EM; ASIIMWE, T. 2019. Farmers' practices and their knowledge of biotic constraints to sweetpotato production in East Africa. Physiological and Molecular Plant Pathology 105: 3-16.

EMBRAPA. Centro Nacional de Pesquisa de Hortaliças. 1995. Cultivo da batata-doce (Ipomoea batatas (L.) Lam). 3. ed. Brasília: Ministério da Agricultura, do Abastecimento e Reforma Agrária (EMBRAPA-CNPH. Instruções Técnicas, 7).

EMBRAPA. Empresa Brasileira de Pesquisa Agropecuária. 2018. SANTOS, GH; JACOMINE, PKT; ANJOS, LHC; OLIVEIRA, VA; LUMBRERAS, JF; COELHO, MR; ALMEIDA, JA; ARAÚJO FILHO, JC; OLIVEIRA, JB; CUNHA, TJF. Sistema Brasileiro de Classificação de Solos - 5. ed.Brasília, DF. 356p.

ERPEN, L; STRECK, NA; UHLMANN, LO; FREITAS, CPO; ANDRIOLO, JL. 2013. Tuberização e produtividade de batata-doce em função de datas de plantio em clima subtropical. Bragantia 72: 396-402.

ESSILFIE, ME; DAPAAH, HK; TEVOR, JW; DARKWA, K. 2016. Number of nodes and part of vine cutting effect on the growth and yield of sweet potato (Ipomoea batatas (L.) Lam) in transitional zone of Ghana. International Journal of Plant \& Soil Science 9: 1-14.

FAO. Food and Agriculture Organization of the United Nations. Available at: < http://www.fao. org/home/en/>. Accessed October 29, 2020.

FERNANDES, AM; RIBEIRO, NP; ASSUNÇÃO, NS; NUNES, JGS; SORROCHE, CP; LEONEL M. 2021. Impact of nitrogen and green manure on yield and quality of sweet potato in sandy soil: A Brazilian case study. Journal of Agriculture and Food Research. 4: 100-131.
GUIMARÃES, LM; OLIVEIRA, AP; BERTINO, AMP; BELEM, AB; FIGUEREDO, JP. 2018. Fitomassa e produção em genótipos de batata-doce na região do brejo paraibano. Agropecuária Técnica 39: 8.

GUIMARÃES, VF; ECHER, MM; MINAMI, K. 2002. Seedlings production and yield of beet plants. Horticultura Brasileira 20: 505-509.

LOEBENSTEIN, G. 2015. Chapter two - Control of sweet potato virus diseases. Advances in Virus Research 91: 33-45.

MA, J; ALONI, R; VILLORDON, A; LABONTE, D; KFIR, Y; ZEMACH, H; SCHWARTZ, A; ALTHAN, L; FIRON, N. 2015. Adventitious root primordia formation and development in stem nodes of 'Georgia Jet' sweetpotato, Ipomoea batatas. American Journal of Botany 102: 1040-1049

MASSAROTO, JA. 2008. Características agronômicas e produção de silagem de clones de batata-doce. Lavras, BR: UFLA. 73p (Ph.D. Thesis).

MASSAROTO, JA; MALUF, WR; GOMES, LAA; FRANCO, HD; GASPARINO CF. 2014. Desempenho de clones de batata-doce. Ambiência 10: 73-81.

MONTEIRO, AB. 2007. Silagens de cultivares e clones de batata doce para alimentação animal visando sustentabilidade da produção agrícola familiar. Cadernos de Agroecologia 2: 2.

MUKHOPADHYAY, SK; CHATTOPADHYAY, A; CHAKRABORTY I; BHATTACHARYA, I. 2011. Crops that feed the world 5. Sweetpotato. Sweetpotatoes for income and food security. Food Security 3: 283-305.

MULI, MB; MWAKINA, D. 2016. Effect of variety and size of stem cutting on flesh root yield and yield components of sweet potato. Journal of Agricultural Science and Technology 6: 175-179.

NASSER, MD; CARDOSO, AII; RÓS, AB; MARIANO-NASSER, FAC; COLOMBARI, LF; RAMOS, JA; FURLANETO, KA. 2020. Produtividade e qualidade de raízes de batatadoce propagadas por diferentes tamanhos de miniestacas. Scientia Plena 16: 7.

NOGUEIRA, CU; NOGUEIRA, HMCM; PADRÓN, RAR; JAHN, SL; MAZUTTI, MA. 2016. Irrigation depth and harvest date in sweet potato for conversion to biofuels. African Journal of Agricultural Research 11: 5116-5123.

OLIVEIRA, AM; BLANK, AF; ALVES, RP; PINTO, VS; BLANK, MFA; MALUF, WR. 2015. Características produtivas de clones de batata-doce cultivados em três períodos de cultivo em São Cristóvão-SE. Horticultura Brasileira 33: 377-382.

PÉREZ-PAZOS, JV; ROSERO, A; MARTÍNEZ, R; PÉREZ, J; MORELO, J; ARAUJO, H; BURBANO-ERAZO, E. 2021. Influence of morpho-physiological traits on root yield in sweet potato (Ipomoea batatas Lam.) genotypes and its adaptation in a sub-humid environment. Scientia Horticulturae 275: 109703.

RÓS, AB. 2017. Produtividade e formato de raízes tuberosas de batata-doce em função do número de gemas enterradas. Cientifica 45: 253-256.

SANTOS, B; FERREIRA, H. 2018. 
Desenvolvimento vegetativo da batata-doce cultivada em consórcio e com diferentes técnicas de plantio. In: Cadernos de Agroecologia. Anais VI Congresso LatinoAmericano, $X$ Congresso Brasileiro, $V$ Seminário do DF e Entorno. Brasilia, BR. p. 6.

SANTOS JUNIOR, RB; SOUZA, TAF; SANTOS, D; FERREIRA, PV; CAVALCANTE, JT. 2020. Agronomic performance of sweet potato genotypes under management of liming and mineral fertilization. Brazilian Journal of Agricultural Sciences 15: 1-5.

SILVA, JBC; LOPES, CA; MAGALHÃES, JS. 2008. Batata-doce (Ipomoea batatas). Available at: $<$ https://sistemasdeproducao.
cnptia.embrapa.br/FontesHTML/Batata-doce/ Batata-doce_Ipomoea_batatas/apresentacao. html $>$. Accessed July $1,2020$.

TESHOME, S; AMIDE, A; BOBO, T. 2020. Adaptability and evaluation of improved orange fleshed sweet potato (Ipomoea batatas L.) varieties in the Mid Altitude of Guji Zone, Southern Ethiopia. Advances in Bioscience and Bioengineering 8: 31-37.

THOMPSON, WB; SCHULTHEIS, JR; CHAUDHARI, S; MONKS, DW; JENNINGS, KM; GRABOW, GL. 2017. 'Covington' sweet potato plant survival and yield response to pre plant irrigation, planting depth, and transplant size. HortTechnology hortte 27: 824-830.

VARGAS, PF; ENGELKING, EW; ALMEIDA,
LCF; FERREIRA, EA; CHARLO, HCO. 2018. Genetic diversity among sweet potato crops cultivated by traditional farmers. Revista Caatinga 31: 779-790.

VARGAS, PF; GODOY, DRZ; ALMEIDA, LCF; CASTOLDI, R. 2017. Agronomic characterization of sweet potato accessions. Comunicata Scientiae 8: 116-125.

YAN, H; LI, Q; ZHANG, Y; KOU, M; TANG, W; WANG, X; LIU, Y; MA, D. 2017. Effects of genotype and planting density on agronomic traits and storage root of sweet potato. Agricultural Science \& Technology 18: 238-246. 